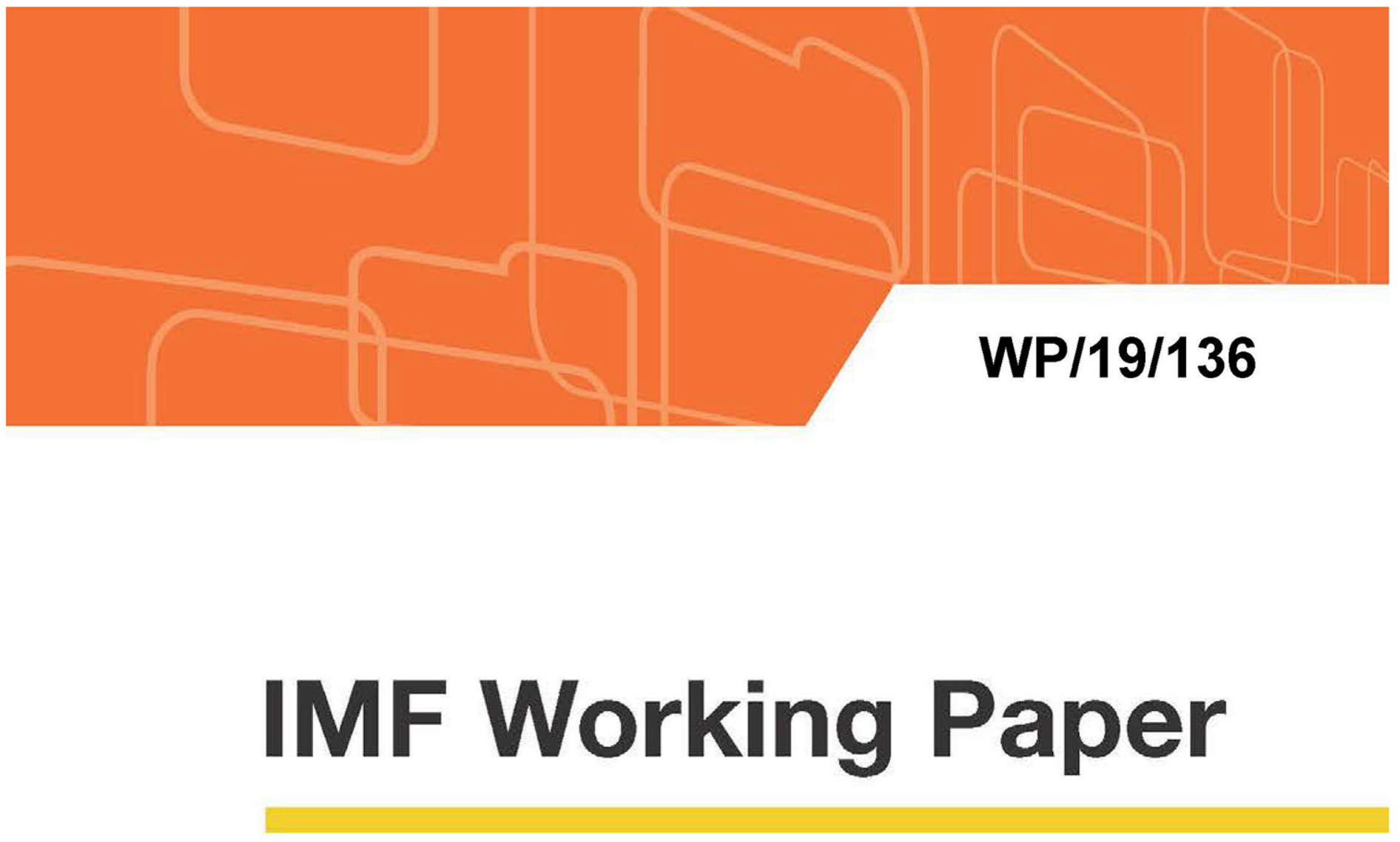

\title{
Anatomy of Sudden Yen Appreciations
}

by Fei Han and Niklas J. Westelius

IMF Working Papers describe research in progress by the author(s) and are published to elicit comments and to encourage debate. The views expressed in IMF Working Papers are those of the author(s) and do not necessarily represent the views of the IMF, its Executive Board, or IMF management.

$$
\text { I N T ER N A T I O N A L M O NETAR Y FU N D }
$$




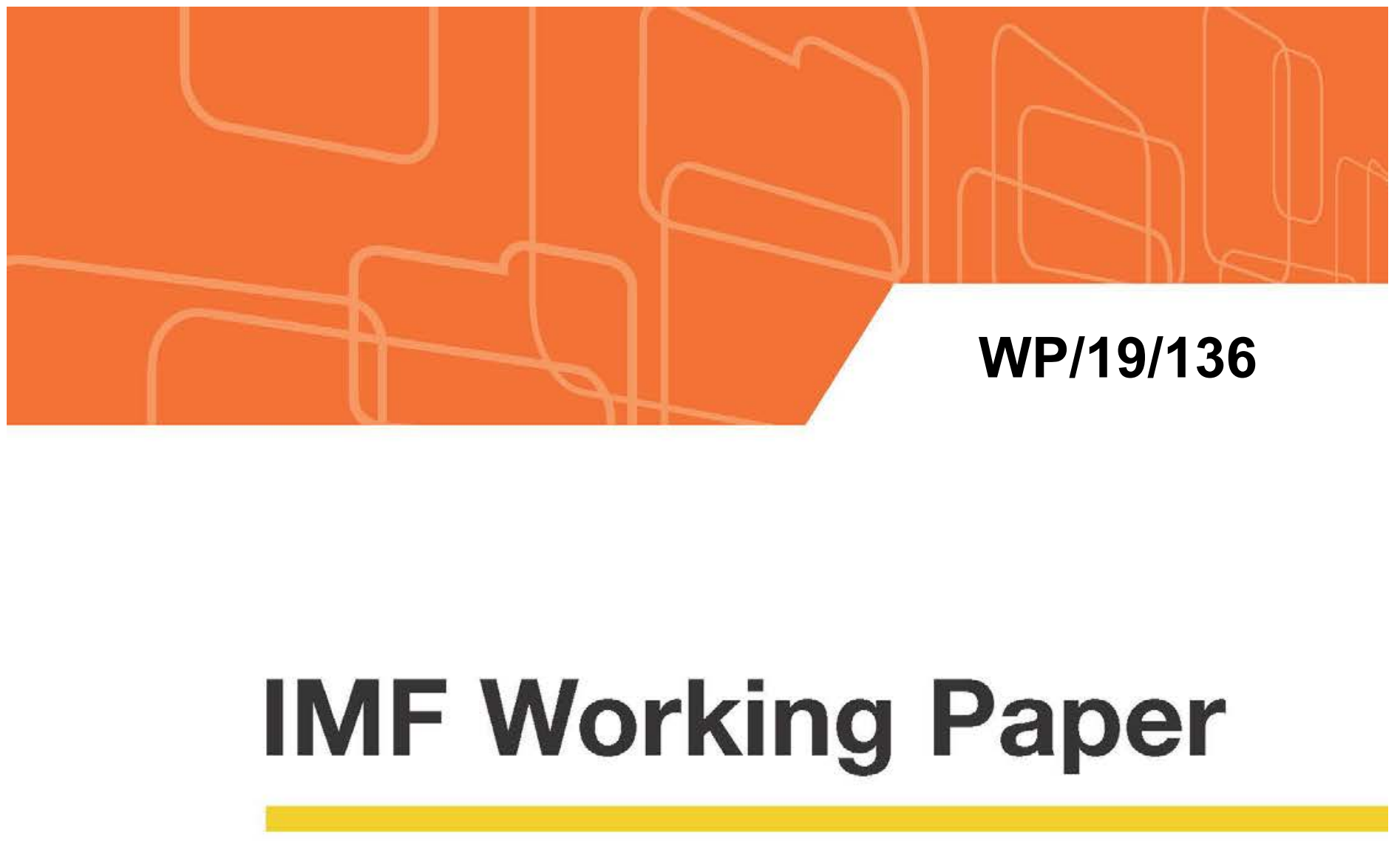

\section{Anatomy of Sudden Yen Appreciations}

by Fei Han and Niklas J. Westelius

IMF Working Papers describe research in progress by the author(s) and are published to elicit comments and to encourage debate. The views expressed in IMF Working Papers are those of the author(s) and do not necessarily represent the views of the IMF, its Executive Board, or IMF management.

$$
\text { I N T E R N A T I O N A L M O N E T A R Y F F N D }
$$




\title{
IMF Working Paper
}

Asia and Pacific Department

\section{Anatomy of Sudden Yen Appreciations}

\section{Prepared by Fei Han and Niklas J. Westelius ${ }^{1}$}

Authorized for distribution by Paul Cashin

July 2019

\section{IMF Working Papers describe research in progress by the author(s) and are published to elicit comments and to encourage debate. The views expressed in IMF Working Papers are those of the author(s) and do not necessarily represent the views of the IMF, its Executive Board, or IMF management.}

\begin{abstract}
The yen is an important barometer for the Japanese economy. Depreciations are typically associated with favorable economic developments such as increased corporate profits, rising equity prices, and upward pressure on domestic consumer prices. On the other hand, large and sharp appreciations run the risk of lowering actual and expected inflation, squeezing corporate profits, generating a negative wealth effect through depressed equity prices, and reducing confidence in the Bank of Japan's efforts to reflate the domestic economy and achieve the inflation target. This paper takes a closer look at underlying drivers of rapid yen appreciations, highlighting the key role of carry-trade and the zero lower bound as important amplifiers.
\end{abstract}

JEL Classification Numbers: C11, C32, E43, E52

Keywords: Carry trade, safe haven effects, exchange rate appreciations, Japan

Authors’ E-Mail Addresses: fhan@,imf.org, nwestelius@,imf.org

\footnotetext{
${ }^{1}$ The authors would like to thank Anh Van Le for her excellent research assistance and are grateful to Paul Cashin, Todd Schneider, Aki Yokoyama (all IMF), Yoshihito Saito (IMF Alternate Executive Director), Kentaro Ogata, Koji Uemura (both Ministry of Finance, Japan), and seminar participants at the Japanese Ministry of Finance for their valuable comments and suggestions. All errors are our own.
} 
Contents

Page

Abstract __ 1

I. Introduction

II. Main Drivers of Short-Run Yen Dynamics ___ $\underline{3}$

III. Three Episodes of Large and Rapid Yen Appreciations ___ $\underline{4}$

IV. Disentangling Exchange Rate Drivers Using a VAR Model ___ 7

V. Results _ $\underline{8}$

VI. Conclusions and Policy Implications

References

\section{Box}

1. The Flash Crash of the Yen on January 4, 2019

$\underline{13}$

\section{Figures}

1. Three Episodes of Large and Sudden Yen Appreciations __ $\underline{5}$

2. Impulse Response Functions ___ 2

3. Impulse Responses of Exchange Rate to an Increase in VIX when VIX is High ___ 11

4. Distribution of Exchange Rate Movement ___ 14

5. Impulse Responses of the Skewness of Distribution of Exchange Rate Movement ___ 15 


\section{INTRODUCTION}

The yen is an important barometer for the Japanese economy. Depreciations are typically associated with favorable economic developments such as increased corporate profits, rising equity prices, and upward pressure on domestic consumer prices. On the other hand, large and sharp appreciations run the risk of lowering actual and expected inflation, squeezing corporate profits, and generating a negative wealth effect through depressed equity prices (see Hogan and Okuma, 2018, Homma et al, 2005, and Botman et al, 2013). ${ }^{1}$ Moreover, large appreciations and accompanying negative effects risk reducing confidence in domestic policies. This is particularly true with respect to the Bank of Japan's efforts to reflate the domestic economy and anchor inflation expectations at the two percent inflation target (see IMF 2018).

This paper takes a closer look at the underlying drivers of rapid yen appreciations, highlighting the key role of carry-trade and the zero lower bound (ZLB) as amplifiers. Based on an event study of three historical episodes and the empirical results from vector autoregression (VAR) models, three main conclusions are put forth.

- A rise in foreign interest rates tends to depreciate the yen. However, it also encourages carry trade activities (i.e., the taking of net short positions in yen), which increases the likelihood of a large appreciation in the yen as the risk of a carry trade reversal increases.

- Heightened uncertainty typically leads to an appreciation of the yen due to safe haven effects, which can be amplified by a reversal in carry trade activities. ${ }^{2}$ Because interest rates in Japan are unable to adjust due to the effective zero lower bound (ZLB), yen appreciation is likely to be more pronounced than that of other safe haven currencies.

- Carry trade reversals typically work as shock amplifiers, making an initial appreciation more pronounced. However, a purely speculative shock that leads to a carry trade reversal can also cause a self-fulfilling appreciation cycle, as yen appreciation leads to further carry trade reversals.

The paper is structured as follows. Section II discusses the main drivers of yen appreciations; section III discusses the anatomy of three specific episodes of sudden yen appreciations; section IV employs a VAR model to disentangle the various drivers of yen appreciations; section V presents the results and section VI concludes.

\section{MAIN DRIVERS OF SHORT-RUN Yen DYNAMICS}

Understanding the drivers of short-run exchange rate movements is notoriously difficult. The analysis presented in this paper takes a parsimonious approach by focusing on three of the most-

\footnotetext{
${ }^{1}$ The negative/positive effect of a yen appreciation/depreciation on corporate profits and equity prices is frequently referenced in the Bank of Japan's quarterly publication on the economic outlook (e.g., BoJ, 2014, and 2016a). In addition, a yen appreciation may affect the profitability of financial institutions as it reduces profits from revenues denominated in foreign currencies (e.g., BoJ, 2016b)

${ }^{2}$ Safe haven appreciations typically occur during heightened market uncertainty/risk-off periods when investors move into assets that are perceived as "safe"- such as Japanese government bonds (JGBs).
} 
cited drivers of sudden short-term yen appreciations: (i) monetary policy shifts, (ii) safe haven effects, and (iii) carry trade reversals.

\section{Monetary policy shifts}

Today's exchange rate should reflect perceptions about the future expected path of interest rate differentials between foreign and domestic (Japanese) short-term interest rates. For instance, a sharp fall in the current or expected U.S. short-term interest rate should lead to an immediate appreciation of the yen relative to the U.S. dollar. Similarly, an improved (higher) inflation outlook for Japan may increase the likelihood of monetary policy normalization, reducing the expected path of the U.S.-Japan interest rate differential and leading to a strengthening of the yen vis-à-vis the U.S. dollar.

\section{Safe haven effects}

During periods of heightened market uncertainty or so-called "risk-off episodes", investors tend to move into currencies that are perceived to have safe haven qualities (i.e., they provide a hedge against potential adverse risk scenarios). A large literature documents that a handful of currencies exhibit this characteristic, including the U.S. dollar, the yen and the Swiss franc (e.g., Ranaldo and Soderlind, 2009). Hence, a rise in market uncertainty tends to be associated with a yen appreciation.

\section{Carry trade reversals}

Carry trade is an investment strategy under which investors borrow in a low-interest rate currency (i.e., the funding currency) and invest in a high-interest currency (i.e., the target currency). For such a strategy to be profitable, the underlying assumption is that exchange rate movements will not eliminate the interest carry over the investment horizon. ${ }^{3}$ Because these positions are leveraged and unhedged, an appreciation of the funding currency (or worries about a future appreciation), can generate a sharp unwinding of these positions which in turn reinforce the initial appreciation. Because Japanese interest rates have been close to zero for about two decades, the yen has been a popular funding currency, making it particularly vulnerable to carry trade reversals.

\section{Three EPISODES OF LARGE AND RAPID YEN APPRECIATIONS}

This section analyzes three episodes of large yen appreciations to illustrate initial triggers and how monetary policy, market uncertainty, and carry trade reversals interact. The episodes were identified by looking at the size of the appreciation (through a threshold methodology) as well as the size and sequencing of the three drivers based on quantitative and narrative records. In each episode, the cumulative appreciation of the yen (vis-à-vis the U.S. dollar) is linked to the evolution of variables intended to capture shifts in the underlying drivers discussed above. In addition, Box 1 discusses the recent "flash crash" of the yen that took place in January 2019.

\footnotetext{
${ }^{3}$ This implicitly assumes that the uncovered interest rate parity does not hold, which tends to be true empirically (see Fama, 1984).
} 


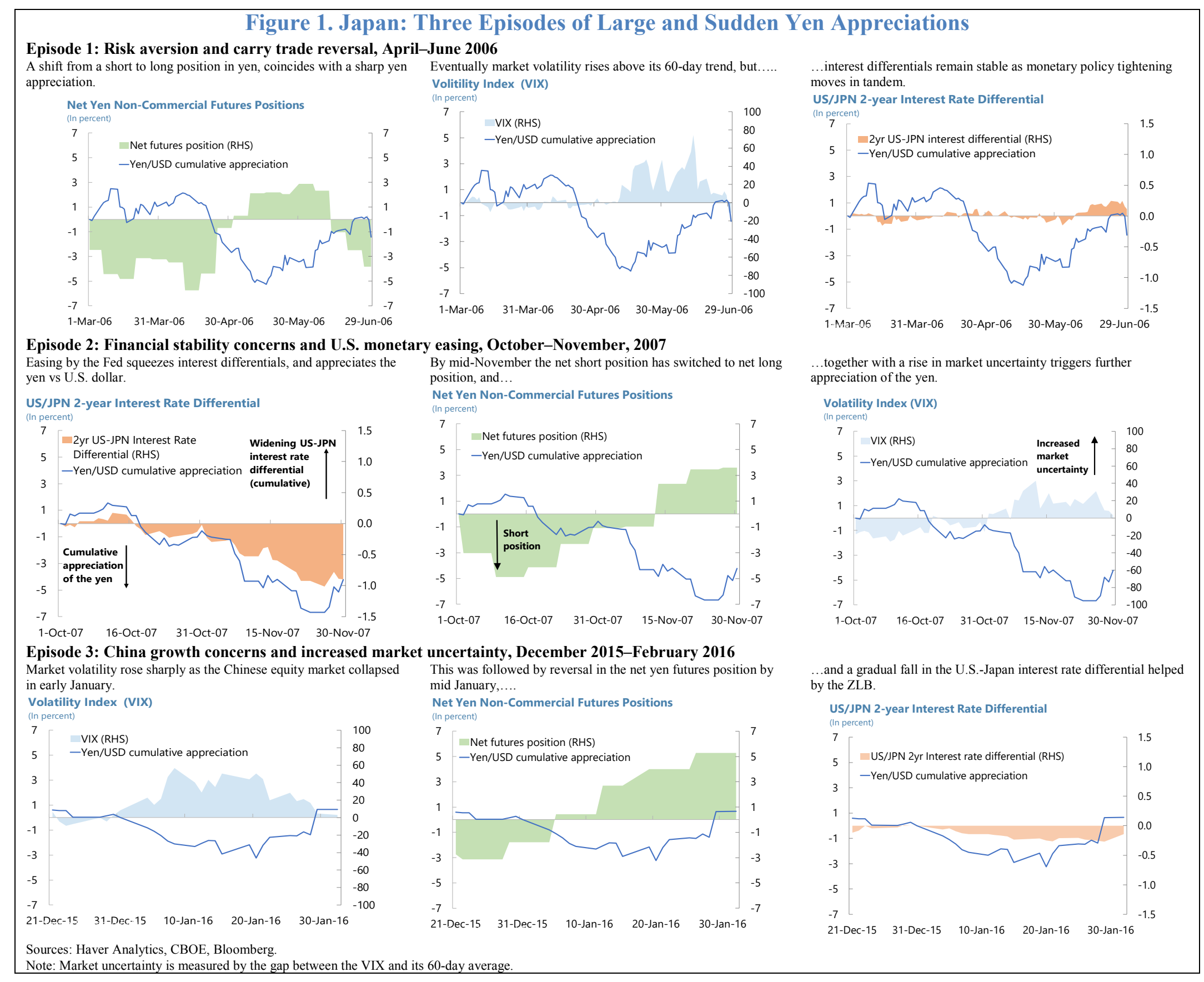


Specifically, the change in the two-year interest rate differential between U.S. and Japan treasury bonds is used to capture actual and expected monetary policy shifts; the CBOE's volatility index (VIX) is used to measure market uncertainty; and the yen net non-commercial futures position is used to capture shifts in unhedged carry trade positions. ${ }^{5}$ Figure 1 shows the cumulative change of the yen/U.S. dollar exchange rate during each episode together with the dynamics of each of the three drivers.

\section{Episode 1: Rising risk perception and carry trade reversal in the spring of 2006}

During 2005, the U.S.-Japan two-year interest rate differential rose by around 100 basis points, causing the yen to depreciate significantly. However, it also created ample incentives to expand carry trade positions. Indeed, the yen net short position of non-commercial futures as well as yen borrowing expanded significantly towards the end of 2005 (Galati and others, 2007). By early 2006, however, risk aversion in global financial markets started to mount, particularly affecting leverage positions in risky assets (IMF, 2006). As a result, investors began to unwind carry trade positions, causing a sharp yen appreciation of more than 5 percent in April-May, 2006. The VIX did not rise above its 60-day average until mid-May, possibly indicating that the carry trade reversal and exchange rate volatility preceded equity market volatility. Moreover, while expectations of monetary policy did tighten during this period as concerns of overheating emerged, the two-year interest rate differential did not move significantly, perhaps reflecting that both the U.S. and Japan were expected to tighten policy in tandem. Nevertheless, the anticipation of tighter liquidity conditions may also have contributed to amplifying the carry trade reversal.

\section{Episode 2: Financial stability concerns and U.S. monetary easing in the second half of 2007}

In September 2007, the U.S. Fed responded aggressively to the ongoing financial crisis by cutting the federal funds rate by 50 basis points. The two-year U.S.-Japan interest rate differential started to fall in mid-October and by end-November it had fallen by 100 basis points. By early November, the yen had appreciated by about 2 percent. With the VIX quickly surpassing its trend and the net yen noncommercial futures position switching from yen short to yen long position (i.e., a carry trade reversal), the yen appreciated sharply in the second half of the month, strengthening by close to 7 percent over the whole episode. In contrast to Episode 1, the carry trade reversal appears to have functioned more as an amplifier than a trigger for Episode 2.

Episode 3: China growth concerns and a spike in market uncertainty, December 2015-February 2016.

\footnotetext{
${ }^{5}$ Following Brunnermeier and others (2008), the net futures position of non-commercial traders is used as a proxy measure for carry trade activity. The net futures positions are calculated by subtracting non-commercial traders' short futures position in yen from their long futures position in yen, both expressed as a fraction of total open interest of all traders. Non-commercial traders are classified as those who do not use futures for hedging purposes by the U.S. Commodity Futures Trading Commission (CFTC). Although this measure only captures the derivatives carry trade activities through futures but not those through forward contracts, it should be a valid indicator for the overall carry trade as the non-commercial traders are basically speculators who use futures to engage in carry trade (Brunnermeier and others, 2008). Daily observations are used for the two-year U.S.-Japan interest rate differential, VIX and exchange rate, while only weekly data is available for the net yen non-commercial position.
} 
On the back of rising concerns of a sharp economic downturn, equity prices in China fell by 18 percent between January 4 and January 18, 2016. With major stock markets following suit and worries of deteriorating global growth, market uncertainty rose sharply. The rise in the VIX - exacerbated by a reversal in carry trade (the yen futures position turned from short to long in early January) - led to a cumulative appreciation of the yen vis-à-vis the U.S. dollar by over 3 percent by January 20. The flight to safety also likely squeezed the U.S.-Japan two-year interest rate differential (as Japan's yield was effectively constrained by the ZLB), further contributing to appreciation pressure.

The three episodes illustrate how changes in underlying exchange rate drivers can trigger sharp yen appreciations that are amplified by a carry trade reversal and falling interest rate differentials. In particular, the 2006 episode shows how rising global interest rates can lead to a buildup of large unhedged carry trade positions. Once a triggering event occurs - such as a rise in risk perception (the 2006 episode), a policy switch (the 2007 episode), or an increase in market uncertainty (the 2016 episode) - the reversal of the carry trade position will lead to an amplification of the yen appreciation. Moreover, during risk-off episodes, the demand for perceived safe assets (e.g., U.S. and Japanese bonds) increases. Because bond yields in Japan are already close to the ZLB, such flows lead to a squeeze in interest rate differentials, which further amplifies the yen appreciation. This could also potentially explain why the yen tends to appreciate even against other safe-haven currencies, during times of heightened global uncertainty.

\section{Disentangling Exchange Rate Drivers Using a VAR Model}

This section uses a VAR model to disentangle the impact of each factor on short-run movement in the U.S. dollar/yen exchange rate. With all three drivers - monetary policy shifts, safe haven effects, and carry trade reversals - endogenously correlated with the exchange rate, a VAR model following Brunnermeier and others (2008) is specified to estimate the impact of each factor. In addition to the three variables used in the event study, the 10-year interest rate differential between the U.S. and Japan is added to capture the difference in the two countries' growth outlooks, which could also affect demand for the two currencies. The VAR model is assumed to be the following

$$
Z_{t}=\beta_{0}+\sum_{j=1}^{J} A_{j} Z_{t-j}+\varepsilon_{t}
$$

where $Z$ is a vector of endogenous variables, including the logarithm of VIX, the two-year and 10-year interest rate differentials between Japan and the U.S., the net futures position of noncommercial traders in yen, and the average daily change in the U.S. dollar/yen exchange rate (averaged to weekly frequency). $Z$ can be written as 


$$
Z=\left[\begin{array}{c}
\log (V I X) \\
i_{2 y}^{J P N}-i_{2 y}^{U S} \\
i_{10 y}^{J P N}-i_{10 y}^{U S} \\
F P^{y e n} \\
\Delta \log (E X R)
\end{array}\right]
$$

The Cholesky decomposition is used to identify each shock in the baseline VAR model, and hence the ordering of the variables matters for the estimates. Therefore, we also re-run the baseline model with different Cholesky orderings and find that the main results discussed in the next section remain more or less unchanged qualitatively. ${ }^{6}$ Moreover, historical decomposition is used to estimate the contributions of each factor to the change in the U.S. dollar/yen exchange rate for each of the three episodes discussed above.

\section{Results}

The impulse response functions suggest that all the factors discussed above could have significant effects on the U.S. dollar/yen exchange rate in the short term. Figure 2 presents the impulse responses of (average daily) exchange rate movement to one-standard-deviation shocks to the logarithm of VIX, the two-year interest rate differential between Japan and the U.S., and the net futures position of non-commercial traders, respectively. ${ }^{7}$ These shocks correspond to an increase in VIX, a narrowing in the interest rate differential between the U.S. and Japan (as the interest rates in the U.S. have been above those in Japan throughout our sample period), and a carry trade reversal.

\section{Uncertainty shock}

A one-standard-deviation increase in $\log (\mathrm{VIX})$, which translates to about 10 percent increase in the level of VIX, could lead to a 0.2 percent appreciation in the yen against the U.S. dollar in the first week. ${ }^{8}$ Moreover, the impulse response of the net futures position in yen to the VIX shock also suggest a significant reversal in carry trade activities - by about 1 percent during the first week and 1.9 percent at its peak during the tenth week - in response to higher uncertainty (see Figure 2, top row).

\footnotetext{
${ }^{6}$ The impact of carry trade reversal on exchange rate movement becomes statistically insignificant only when it is ranked last in the Cholesky ordering, while the effects of other shocks remain qualitatively unchanged. Moreover, the main qualitative results also hold when we include the EPFR fund flow data - a proxy measure of capital flows at weekly frequency.

${ }^{7}$ The impulse responses to a shock to the 10-year interest rate differential are suppressed from Figure 2 as they are qualitatively similar to those to a shock to the 2-year interest rate differential albeit with less statistical significance.

${ }^{8}$ Notice that the impulse responses of exchange rate movement presented in Figure 2 are average daily percent changes.
} 
Figure 2. Japan: Impulse Response Functions ${ }^{1}$

I. Impulse responses to an increase in $\mathrm{VIX}^{2}$
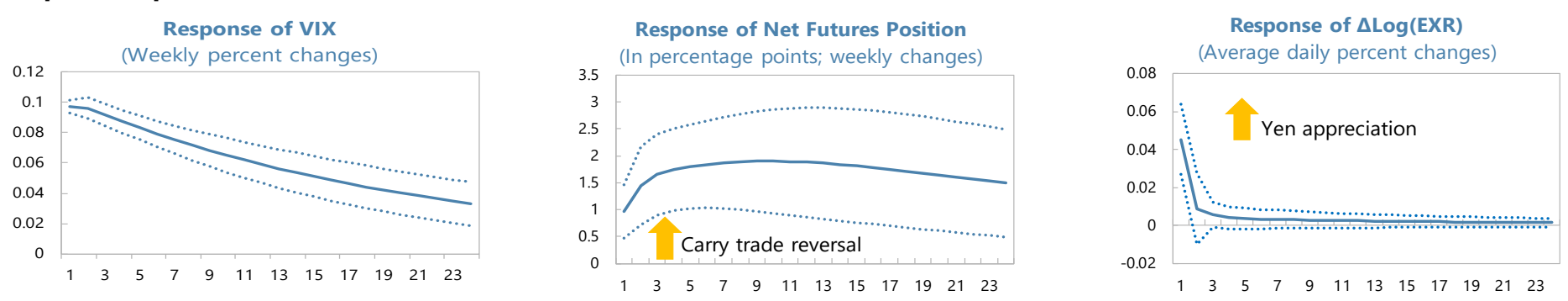

II. Impulse responses to a narrowing in the two-year interest rate differential ${ }^{3}$
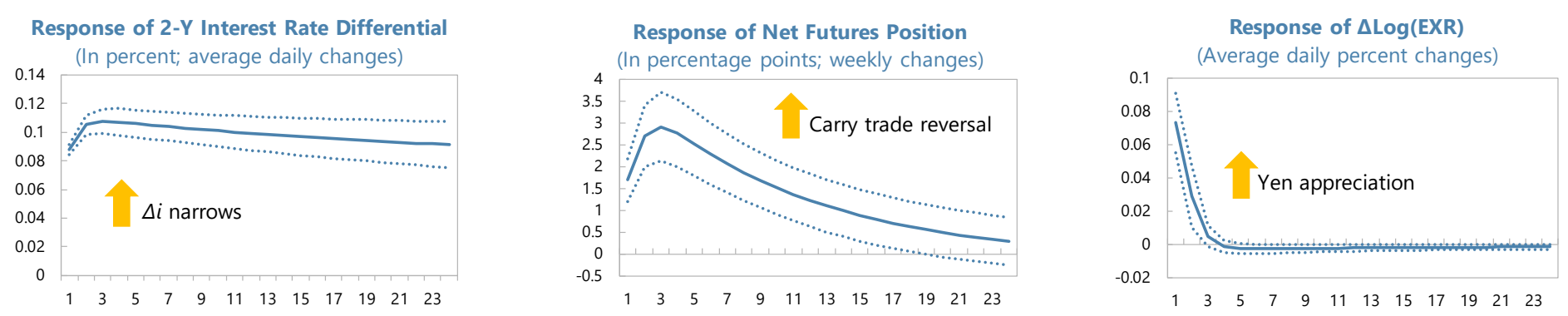

III. Impulse responses to a carry trade reversal ${ }^{4}$
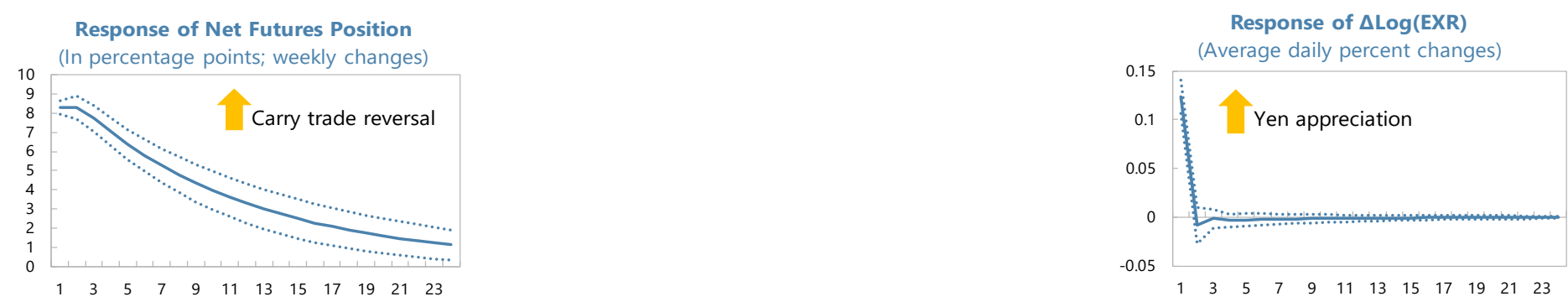

Sources: Haver Analytics; U.S. Commodity Futures Trading Commission (CFTC); and IMF staff estimates.

${ }^{1}$ The error bands are $+/-2$ standard errors. The $\mathrm{x}$-axis shows the time horizon in weeks.

${ }^{2}$ The shock is a one-standard-deviation shock to $\log (\mathrm{VIX})$.

${ }^{3}$ The shock is a one-standard-deviation shock to the 2-year interest rate differential. Since the 2-year interest rate in the U.S. has been above that of Japan throughout our sample period, an increase in the interest rate differential between Japan and the U.S. indicates a narrowing in the interest rate differential between the U.S. and Japan.

${ }^{4}$ The shock is a one-standard-deviation shock to the net futures position of non-commercial traders in yen. 


\section{Interest rate shock}

If the two-year interest rate differential between the U.S. and Japan narrows by one standard deviation, which is about 0.1 percentage points, then the yen is likely to appreciate by about 0.4 percent during the first week. ${ }^{9}$ In contrast, a widening in the interest rate differential due to rising interest rates in the U.S. could encourage carry trade activities and depreciate the yen (see Figure 2, middle row).

\section{Carry trade shock}

A one standard deviation pure speculative shock to carry trade activities, which translates to about an 8 percent decline in the net futures position of noncommercial traders in yen, could lead to a 0.6 percent appreciation in the yen against the U.S. dollar in the first week (see Figure 2, bottom row). ${ }^{10}$ This significant impact of carry trade reversal on yen appreciation, together with the earlier finding that the carry trade position tends to unwind in response to the VIX shock, suggests that carry trade could be an amplification channel for yen appreciation when uncertainty rises. Moreover, the results suggest that a shock to the exchange rate could lead to a further reversal in carry trade positions, triggering a self-fulfilling appreciation cycle. ${ }^{11}$

An increase in uncertainty could have a larger impact on yen appreciation when the level of uncertainty is already high, which is due partly to a faster reversal in the carry trade position. We re-run the VAR model using a subsample when VIX is above its $90^{\text {th }}$ percentile. The impulse response functions, along with those estimated from the full sample for a better comparison, are presented in Figure 3. As we can see from Figure 3 (top row), the standard deviation of VIX did not change between the full sample and the subsample. However, the impact of a one-standarddeviation increase in $\log$ (VIX) when the subsample is used is about three times as large as compared to the full sample (Figure 3, middle row). By examining all the impulse response functions between the two models, we find that the carry trade position unwinds much faster in the first week after the shock when uncertainty (VIX) is above its $90^{\text {th }}$ percentile - about two times the speed that carry trade unwinds when VIX is at its average (see Figure 3, bottom row). This suggests that the amplification of the uncertainty shock by carry trade reversal could be greater when the level of uncertainty is high.

\footnotetext{
${ }^{9}$ The narrowing in the interest rate differential between the U.S. and Japan could happen when U.S. interest rates decline while interest rates in Japan remain constant under its Yield Curve Control (YCC) policy.

${ }^{10}$ The pure speculative shock to carry trade activities is orthogonal to the shocks to VIX and interest rate differentials in the baseline VAR model (1).

${ }^{11}$ The impulse response of carry trade position (i.e., the net futures position in yen) to a shock to the exchange rate movement is suppressed from Figure 2 but available upon request.
} 
Figure 3. Japan: Impulse Responses of Exchange Rate to Increase in VIX when VIX is High ${ }^{1}$

Full sample since 1996

Response of VIX
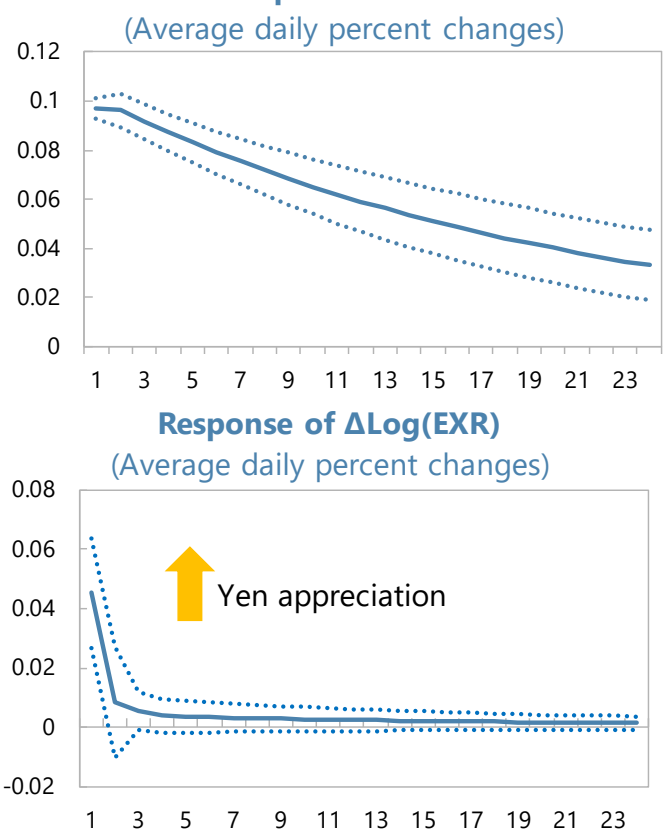

Response of Net Futures Position

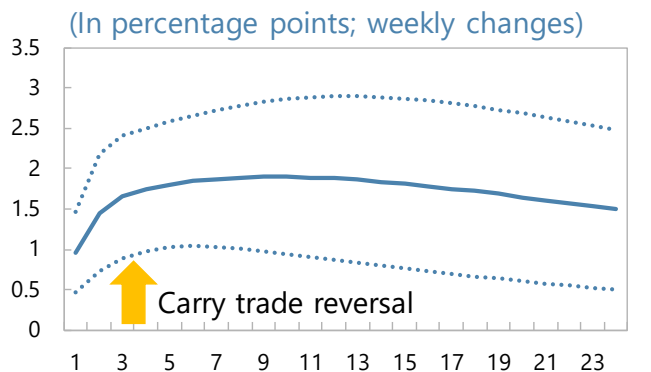

Subsample when VIX is high

Response of VIX

(Average daily percent changes)

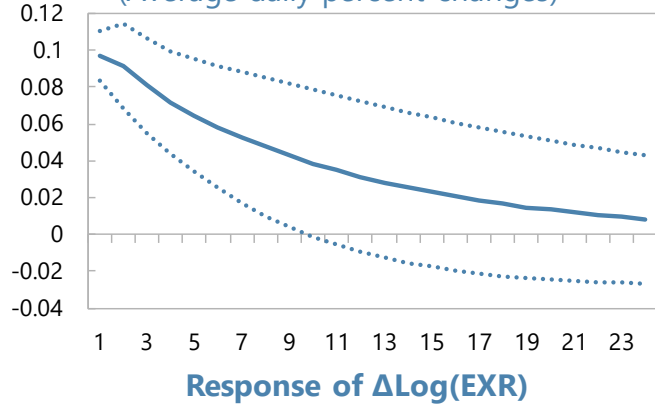

(Average daily percent changes)

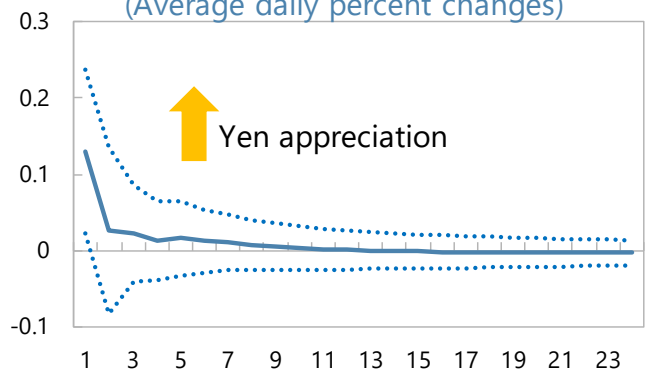

Response of Net Futures Position

(In percentage points; weekly changes)

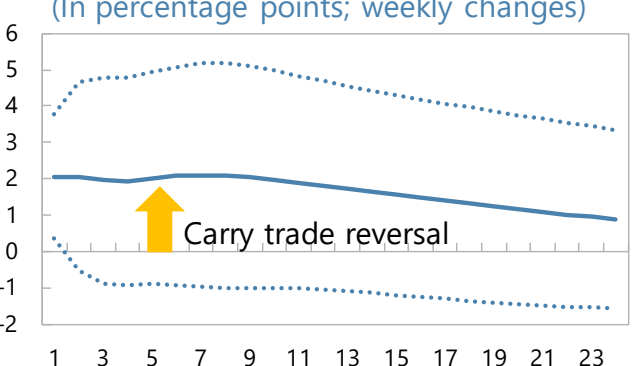

Sources: Haver Analytics; U.S. Commodity Futures Trading Commission (CFTC); and IMF staff estimates.

${ }^{1}$ The shock is a one-standard-deviation shock to $\log (\mathrm{VIX})$, and the error bands are $+/-2$ standard errors. For better comparison, we include the impulse response functions estimated with the full sample and a subsample when VIX is greater than or equal to its $90^{\text {th }}$ percentile in the two columns, respectively. The $\mathrm{x}$-axis shows the time horizon in weeks.

Historical decomposition is used to better analyze and disentangle the contributions of each factor to the exchange rate movement. We use the three episodes of large yen appreciation identified previously to illustrate how the four factors contribute in their own way to the strengthening of the yen against the U.S. dollar. The text figures below show the historical decomposition of cumulative exchange rate movements since the beginning of each episode for all the three episodes. A more recent episode of yen "flash crash" on January 4, 2019 also showed the importance of carry trade activities in driving the yen/U.S. dollar dynamics (see Box). 
- Rising risk perception and carry trade reversal in the spring of 2006. In line with the event study, the yen appreciation in the first episode is mostly explained by a carry trade reversal (see figure). The carry trade reversal alone explains over 40 percent of the peak cumulative appreciation of the yen. The impact is somewhat mitigated by the depreciation effects from a decline in the VIX at the beginning of the episode, and a widening in the 10-year interest rate differential between the U.S. and Japan.

- Financial stability concerns and U.S. monetary easing in 2007. As expected, the yen appreciation in the second episode is mainly driven by a narrowing in the two-year interest rate differential between the U.S. and Japan (by about 70 basis points), which contributed about 40 percent of the peak cumulative appreciation in the yen (see figure).

- Heightened uncertainty and China's growth concerns in 2016. In the third episode with a spike in market uncertainty, both VIX and carry trade reversal played a significant role in driving the yen appreciation. These two factors together explained more than 60 percent of the peak cumulative appreciation in the yen. The two-year interest rate differential also contributed to the yen appreciation although only at a later stage.

In addition to amplifying the impact of higher
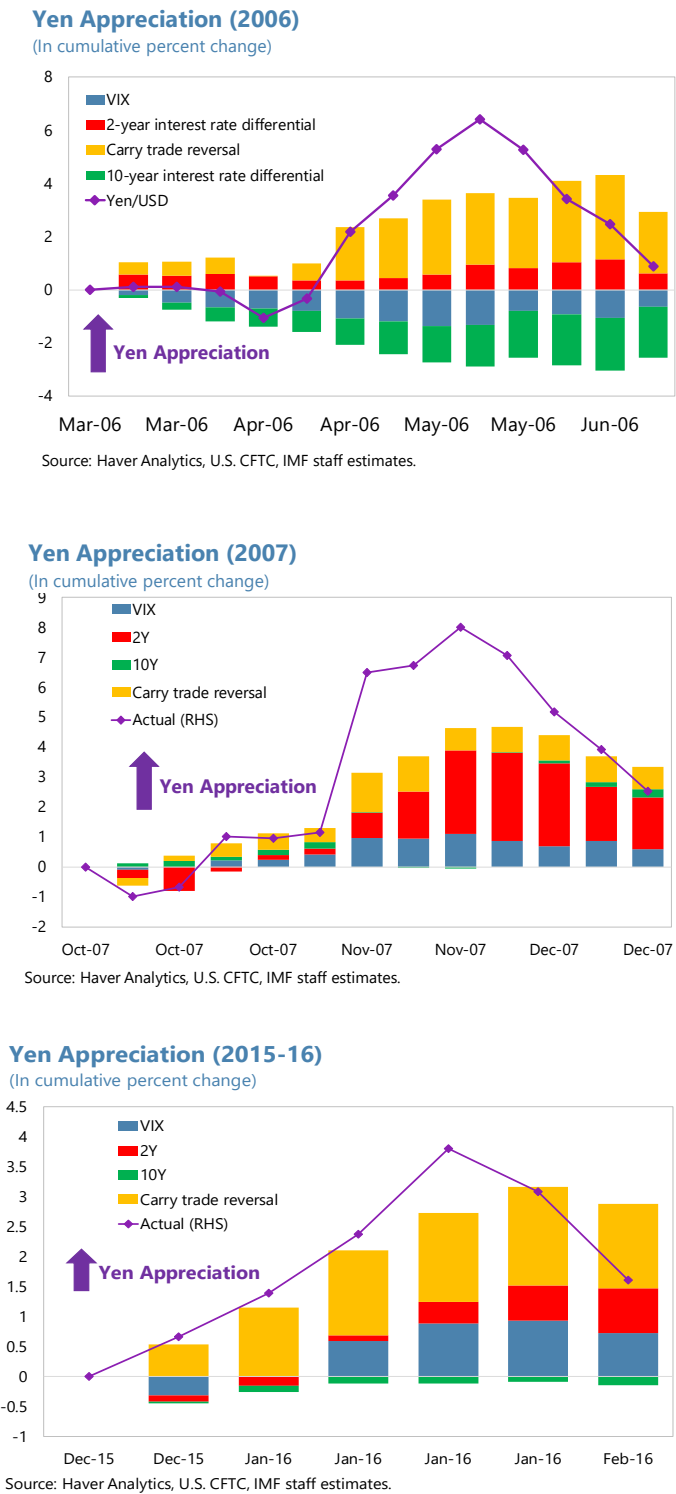
uncertainty on the size of yen appreciation, carry trade may also increase the likelihood of a large appreciation. The leveraged nature of carry trade implies that its impact on the U.S. dollar/yen exchange rate may be asymmetric, as the use of margin calls in the event of adverse movement of the exchange rate (relatively higher value of the yen) can force the unwinding of carry trade positions, but there is no similar forced action when the exchange rate moves favorably (Gagnon and Chaboud, 2007). Therefore, we should expect that the historical distribution of exchange rate movements is skewed towards the appreciation of currencies with low interest rates (such as the yen) and the depreciation of currencies with high interest rates (such as the U.S. dollar). In this context, the skewness of the distribution of exchange rate movement could be an indicator of the likelihood of a large yen appreciation. In particular, if the skewness towards appreciation of yen increases, then we should expect a higher likelihood of large yen appreciations. One may also expect that carry trade activities could affect the skewness. 


\section{Box. The Flash Crash of the Yen on January 4, 2019}

At 5:35 pm (ET) on Wednesday January 2, the Japanese yen appreciated sharply against several currencies - all within the span of a minute. The intraday yen appreciation was particularly marked against the Australian dollar (11 percent), the Turkish lira (8 percent) and the U.S. dollar (4 percent), where it took only moments for the yen to surge through levels that have held for almost a decade.

The momentum behind this event likely started an hour earlier when Apple Inc. announced disappointing fourthquarter revenues due to slowing sales in China-stoking fears of a global economic slowdown. In line with the safe haven hypothesis, the yen began to gradually appreciate. However, the "flash crash" of the yen was likely triggered by a combination of two factors: low market liquidity and a carry trade reversal.

- Low liquidity: The flash crash took place during the "Asian witching hour." This is the daily period of low liquidity between the close of FX trading in New York and the beginning of FX trading in Tokyo. Moreover, many Japanese banks who acts as market makers were closed for a public holiday. Indeed, the bid-ask spread (which is typically used as a measure of market liquidity) widened substantially during the episode. ${ }^{1}$

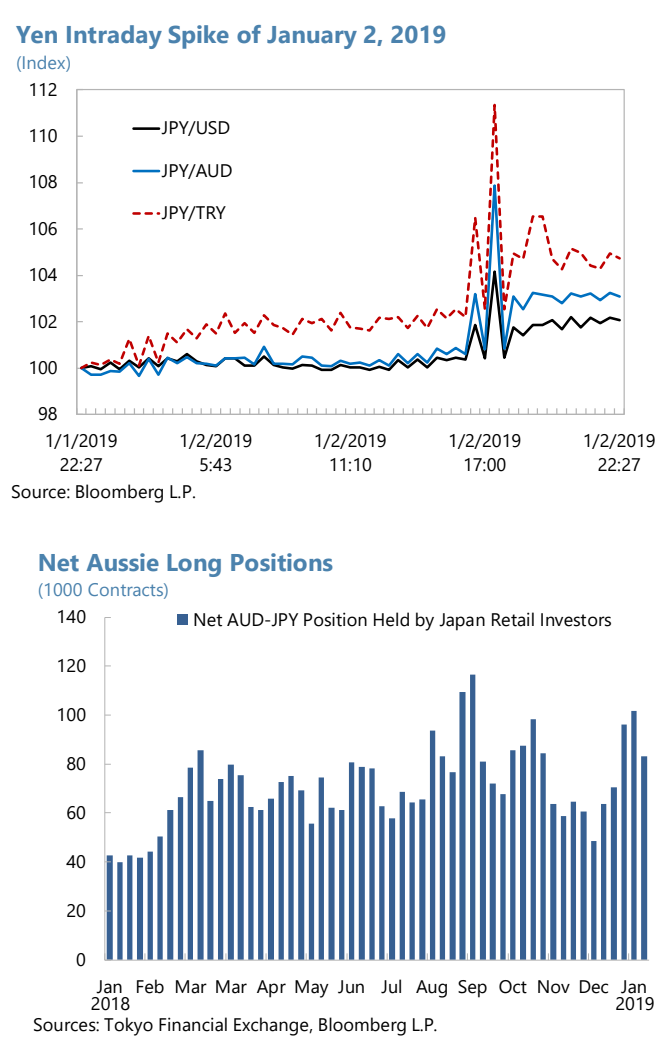

- Carry trade reversal: Leading up to the event, VIX surged rapidly amid pessimism over global growth and Japanese retail investors' net long positions of high yielding currency increased significantly (see figure). Once the gradual safe haven appreciation reached a certain threshold, stop-loss triggers by carry traders were activated. This led to a significant reversal in carry trade positions and further increased the demand for yen. Historical decomposition from the VAR model suggests that carry trade reversal contributed substantially to the sharp yen appreciation or "flash crash" (see figure).

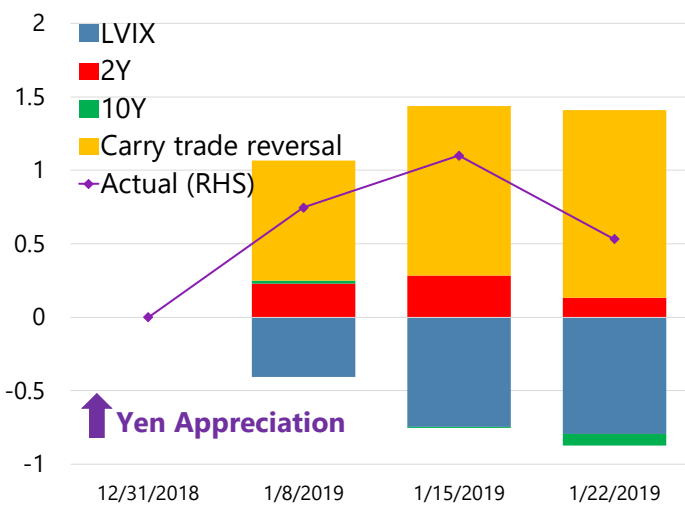

By the end of the witching hour, upward pressure on the yen had diminished. However, the yen did not fully depreciate back to its pre-spike level and continued to trade in a narrow range against major currencies for a while. Overall, the January 2019 episode provides another example of how carry trade reversals and market conditions can amplify safe haven appreciations of the yen.

1/ See “The Recent Japanese Yen Flash Crash,” Statement on Monetary Policy, Reserve Bank of Australia, February 2019. 
A higher U.S.-Japan interest rate differential could encourage unhedged carry trade activities and increase the likelihood of a large yen appreciation as those carry trade positions are rapidly reversed. Given that interest rate differentials are the key underlying factor for carry trade activities, they may also affect the likelihood of a large yen appreciation. Figure 4 plots the estimated kernel density of the daily U.S. dollar/yen exchange rate movement conditional on the two-year interest rate differential between the U.S. and Japan. The two densities correspond to two conditional distributions when the interest rate differential is low (below 2.5 percent) and when it is high (greater than or equal to 2.5 percent), respectively. In line with Brunnermeier and others (2008), the figure also suggests that the distribution is skewed towards appreciation of the yen. More specifically, there was almost no daily appreciation in the yen of over 1 percent when the interest rate differential was low, but such a likelihood increases to about 1 percent when the interest rate differential is high.

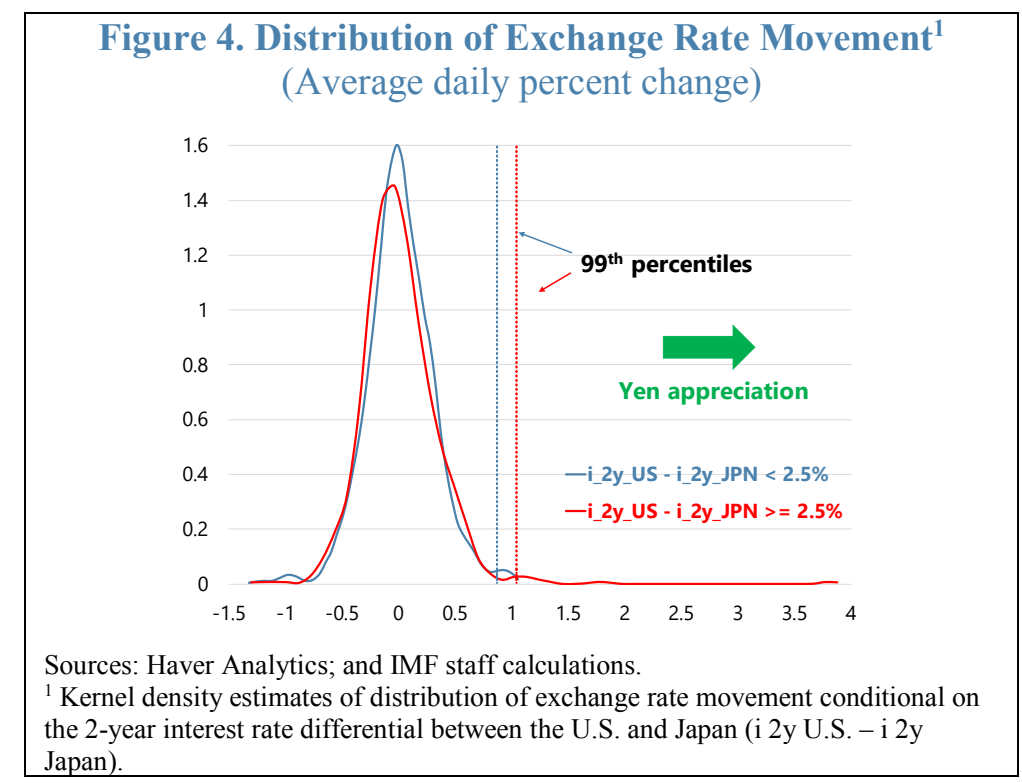

A measure of the skewness of the distribution of exchange rate movement is added to the baseline VAR model to estimate the impact of each factor on the likelihood of a large yen appreciation. We calculate the skewness of the time series of the daily U.S. dollar/yen movement on a three-month rolling basis as a measure of the likelihood of a sharp yen appreciation. We then average the daily skewness measure to the weekly frequency and, following Brunnermeier et al (2008), add it to the vector $Z$ in the baseline VAR model to analyze the impact of the four factors discussed above. We find that both the two-year interest rate differential and the carry trade reversal had statistically significant effects on the skewness measure (Figure 5). In particular, the effect of the two-year interest rate differential on skewness is only significant in the medium term (a few months after the shock), while that of the carry trade reversal is very short lived. 


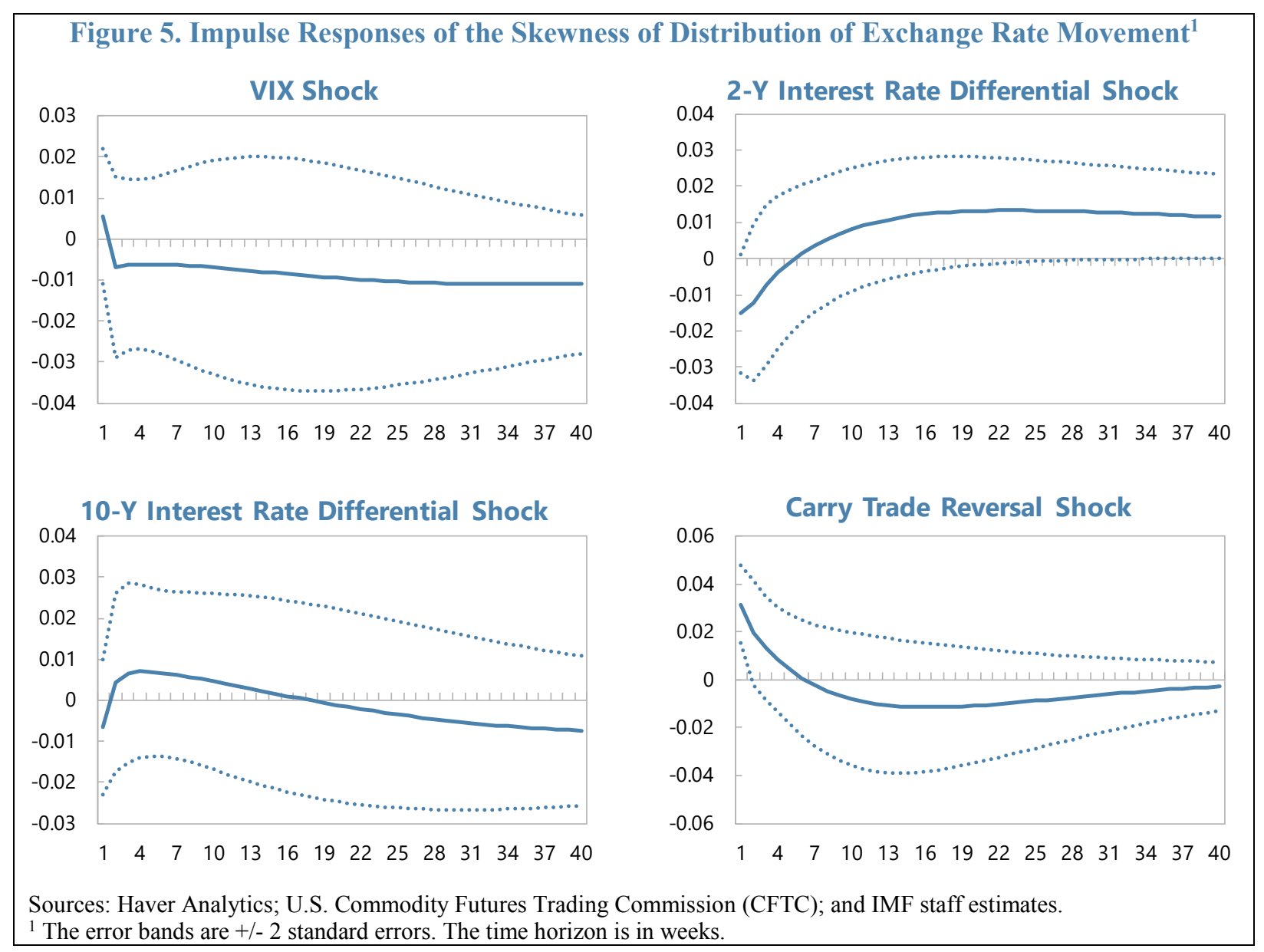

\section{Conclusions And Policy Implications}

Based on an event study and impulse responses from a VAR model, this study highlights the importance of carry trade as an amplifier of yen appreciations. Heightened uncertainty can lead to an appreciation in the yen through so-called "safe-haven effects", which tend to be amplified by carry trade reversals as exchange rate uncertainty rises. Moreover, the same increase in uncertainty could have a larger impact on the yen-U.S. dollar exchange rate movement when the level of uncertainty is high, which can be attributed partly to a greater amplification by carry trade reversal. Purely speculative shocks that cause a carry trade reversal can also lead to a selffulfilling appreciation cycle, as the yen appreciation leads to further unwinding of carry trade positions.

U.S. monetary policy normalization and a continuation of Japan's Yield Curve Control policy may encourage unhedged carry trade activities and increase the likelihood of large yen appreciations as those carry trade positions are rapidly reversed. The empirical results suggest that higher interest rates in the U.S. tend to depreciate the yen and encourage carry trade activities, which, however, increases the likelihood of a large yen appreciation later on. Although the depreciation trend of the yen amid widening interest rate differentials could benefit the 
Japanese economy going forward, an unwinding of the increased carry trade positions could reverse the depreciation and lead to rapid appreciations. The authorities should keep in mind this exchange rate risk and continue to closely monitor carry trade activities. 


\section{REFERENCES}

Bank of Japan, 2014a, “Outlook for Economic Activity and Prices”, April 2014.

Bank of Japan, 2016a, “Outlook for Economic Activity and Prices”, October 2016.

Bank of Japan, 2016b, “Comprehensive Assessment: Developments in Economic Activity and Prices as well as Policy Effects since the Introduction of Quantitative and Qualitative Monetary Easing (QQE).”

Botman, D., I. de Carvalho Filho, and W.R. Lam, 2013, “The Curious Case of the Yen as a Safe Haven Currency: A Forensic Analysis," IMF Working Paper 13/288.

Brunnermeier, M.K., S. Nagel, and L.H. Pedersen, 2008, "Carry Trades and Currency Crashes," NBER Macroeconomics Annual, Vol. 23, pp. 313-47.

Fama, E., 1984, "Forward and Spot Exchange Rates," Journal of Monetary Economics, Vol. 14, pp. 319-38.

Gagnon, J.E., and A.P. Chaboud, 2007, "What Can the Data Tell Us about Carry Trades in Japanese Yen?” International Finance Discussion Papers, Board of Governors of the Federal Reserve System.

Galati, G., A. Heath, and P. McGuire, 2007, “Evidence of Carry Trade Activity,” BIS Quarterly Review, Bank of International Settlements: Basel.

Habib, M.M., and L. Stracca, 2012, “Getting Beyond Carry Trade: What Makes a Safe Haven Currency?” Journal of International Economics, Vol. 87, pp. 50-64.

Hogan, Y., and R. Okuma, 2018, "Inflation Expectations in Japan: A Learning-Approach Perspective,” Bank of Japan Working Paper Series, No 18-E-8.

Homma, T., Y. Tsutsui, and U. Benzion, 2005, “Exchange rate and stock prices,” Applied Financial Economics, Vol. 15, pp. 469-478.

Hossfeld, O., and R. MacDonald, 2015, "Carry Funding and Safe Haven Currencies: A Threshold Regression Approach,” Journal of International Money and Finance, Vol. 59, pp. 185-202.

International Monetary Fund, 2006, Financial Market Update, International Capital Markets Department.

International Monetary Fund, 2018, “Japan: Article IV Consultation Staff Report,” IMF Country Report No. 18/333.

Ito, T., 2015, "The Plaza Agreement and Japan: Reflection on the 30th year Anniversary," Working Paper, Rice University’s Baker Institute for Public Policy, Houston. 
Ranaldo, A., and P. Soderlind, 2009, "Safe Haven Currencies," Review of Finance, Vol. 14, pp. 385-407. 